\title{
ТИПИ МІЖПОКОЛІННОЇ КОМУНІКАЦІї ЯК МЕХАНІЗМУ СОЦІОКУЛЬТУРНОЇ СПАДКОЄМНОСТІ
}

\section{- Макарова Марія Володимирівна}

- Кандидат культурології, доцент,

ORCID: 0000-0001-7543-0361, e-mail: student61@ukr.net,

Київський університет імені Бориса Грінченка,

вул. Бульварно-Кудрявська, 18/2, Київ, Україна, 04053

\section{- Для цитування:}

Макарова, М.В. (2019). Типи міжпоколінної комунікації як механізму соціокультурної спадкоємності. Питання культурології, (35), 205-213. doi: https://doi.org/10.31866/24101311.35.2019.188810.

\section{- Анотація}

Мета статті. Охарактеризувати сутність комунікації між різними поколіннями в процесі розвитку суспільства, обумовленої її специфікою та відмінностями від усіх інших видів соціальних комунікацій. Адже ні професійна, ні міжособистісна, ні педагогічна, ні масова комунікації не $є$ такою ж мірою джерелом історичного розвитку. Методологія дослідження полягає у застосуванні загальнонаукових методів і підходів, зокрема діалектичного, що дає можливість розглянути соціальні та комунікативні процеси в їх органічній цілісності, проаналізувати сутність комунікації між різними поколіннями в конкретно-історичних соціальних системах. З'ясувати, як одночасно з розвитком суспільства відбувається видозміна міжпоколінної комунікації, а також виявити суперечності в просторі останньої. Актуальність дослідження продиктована тим, що між поколіннями формується простір нерозуміння, взаємного відторгнення, неприйняття, виникає «зона мовчання». Наукова новизна полягає у виявленні сутності комунікації у різних типах суспільств за типологією М. Мід та М. Петрова. Висновки. З'ясовано, що процеси міжпоколінної комунікації відбуваються в суспільстві, як правило, спонтанно, в залежності від його типу, структури влади, соціально-економічних відносин та ін. Виявлено, що незабезпечення міжпоколінної комунікації зв'язку між минулим, теперішнім і майбутнім стає умовою появи певних деструктивних елементів, оскільки орієнтація тільки на теперішнє та специфріка сучасної соціалізації вносять розрив у діалог поколінь. Доведено, що в умовах кризи суспільного розвитку міжпоколінний комунікативний простір починає фрормуватися в процесі соціалізації поколінь. Тому для напрацювання способів запобігання розриву спадковості в культурі постає необхідність в особливій увазі до дослідження конфліктів у міжпоколінній комунікації.

Ключові слова: міжпоколінна комунікація; діалог поколінь; культура; постфігуративне суспільство; кофрігуративне суспільство; префрігуративне суспільство 


\section{- Вступ}

Комунікація як предмет наукового пізнання сформувалася нещодавно. Передумови до вироблення теорії соціальної комунікації складалися в різних наукових напрямах: філософрії, психології, семіотиці і соціолінгвістиці, педагогіці, культурології, соціології. Так, загальну теорію комунікацій розробив соціолог і культуролог М. Маклюен (McLuhan, 1994). Він же запропонував класифрікацію типів комунікативності, серед яких виокремив функціонально-рольовий тип поколінних і міжпоколінних комунікацій. На думку вченого, цей тип комунікації розвивається в міському середовищі в умовах значної диференціації типів діяльності та способу життя i $є$ безособовим і спеціалізованим. Правила такої комунікації загалом відповідають поколінній ролі, яку індивід відіграє в певній просторово-часовій ситуації. Усні, а ще більше письмові контакти часто формалізовані, ієрархічні, більш цілеспрямовані і раціоналізовані. Наприклад, містяни не вступають зазвичай у спілкування на вулиці або в міському транспорті, у фрункціональному середовищі виникають правила знайомства. В актах міжпоколінної комунікації відбувається не просто обмін інформацією, але формування самого суб'єкта історії - покоління, яке і забезпечує хід історичного розвитку. Значення покоління в історичному розвитку залежить від того, наскільки воно залучено в міжпоколінну комунікацію: повноцінне його включення працює на спадкоємність, історичний розвиток у руслі гегелівського розуміння «заперечення заперечення», виключення ж нових поколінь із цього процесу знаменує появу анархістських поколінь, які відмовляються від спадщини попередників. Така важлива роль міжпоколінної комунікації в процесі розвитку суспільства обумовлює її специфріку, відмінність від усіх інших видів соціальних комунікацій: ні професійна, ні міжособистісна, ні педагогічна, ні масова комунікації не $є$ такою ж мірою джерелом історичного розвитку. Актуальність дослідження продиктована тим, що між поколіннями формується простір нерозуміння, взаємного відторгнення, неприйняття, виникає «зона мовчання». Безперечно, це послаблює процеси формування культурної ідентичності, знижує імунітет молодих поколінь до бездуховності і зрештою загрожує розривом спадкоємності в культурі.

Сьогодні із проблеми взаємовідносин поколінь переважають дві точки зору. Одні автори вважають, що міжпоколінний розрив переростає у глобальну проблему (Мид, 1988). Інші підкреслюють маятниковий характер міжпоколінних взаємин. На їх думку, періоди конфліктів чергуються з періодами спадкоємності (Ортега-и-Гассет, 2016; Feuer, 1969).

Незважаючи на велику, здавалося б, кількість літератури з проблем поколінь і комунікації, не існує спеціальних робіт, присвячених з'ясуванню сутності міжпоколінної комунікації, аналізу її ролі в історичному процесі, розгляду тих явищ, які ускладнюють або повністю блокують процес ії̈ здійснення.

\section{- Мета статті}

Метою дослідження є характеристика сутності міжпоколінної комунікації в різних типах суспільств. А для виявлення особливостей процесу міжпоколінної комунікації ставиться завдання, застосовуючи діалектичний метод, проаналізувати відносини між поколіннями; спираючись на зіставлення типологій 
суспільств за М. Мід та М. Петровим, з'ясувати, як із розвитком суспільства видозмінюється міжпоколінна комунікація, виявити суперечності в просторі останньої.

\section{- Виклад матеріалу дослідження}

Міжпоколінну комунікацію сьогодні прийнято розглядати як процес успадкування культури, який можна представити в єдності чотирьох рівнів:

- ідеологічного (культура пізнання і мислення, аналіз й узагальнення соціального досвіду, здатність творчого осмислення нових явищ на основі раніше набутих знань);

- емоційно-психологічного (переконаність в істинності нових знань);

- діяльнісного, поведінкового (готовність і здатність до повсякденної реалізації своїх ідеалів);

- аксіологічного (передання основних настанов і принципів світорозуміння, ціннісних і моральних норм, досвіду взаємовідносин).

Діалог поколінь передбачає взаємодію різних свідомостей, що вирізняються не лише знаннями, способами оволодіння реальністю, а й якісними відмінностями в організації тієї чи іншої свідомості, які залежать від сприйняття й освіти, життя в певному культурному середовищі. Перефрразовуючи Б. Парахонського (1989), міжпоколінна комунікація - «це свого роду комунікативно-епістемічна система, в якій із самого початку передбачається наявність різних свідомостей» (с. 24), що мають від початку комунікативний характер, а не зводяться до структур діяльності як своєї основи. Міжпоколінну комунікацію, таким чином, можна визначити як процес взаємодії представників різних поколінь, у ході якого реалізуються культурозберігаюча, культуротворча функції поколінь, процес, під час якого суб'єкти комунікації обмінюються результатами діяльності, інфоормацією, духовно збагачують один одного.

Взаємини між поколіннями вказують на спадкоємність, нехай навіть різної міри, зв'язок минулого із сьогоденням і майбутнім. Ці три тимчасові компоненти культурного поля будь-якої сучасності в різних суспільствах представлені в різних пропорціях: в одних, наприклад, традиційних культурах, переважає орієнтація на минуле, в інших, наприклад, прогресистських, - орієнтація на майбутнє. Але для того, щоб ланцюг історії і культурної ідентичності не перервався, міжпоколінна комунікація покликана підтримувати стан динамічної рівноваги, яким «закладається» ефрект присутності минулих, нинішніх і майбутніх поколінь.

Американський антрополог і соціолог М. Мід (Мид, 1988) описує розроблену нею типологізацію міжпоколінних відносин, вводячи як один із її критеріїв часову складову в міжпоколінній комунікації. На підставі цього критерію М. Мід виокремлює три типи суспільства (постфігуративне, кофрігуративне і префігуративне) i, відповідно, три типи міжпоколінної комунікації. Автор вказує, що традиційне, патріархальне суспільство, назване нею постфігуративним, орієнтується на традицію і ії̈ живих носіїв - людей похилого віку. Постфрігуративну культуру вона визначає як «культуру, в якій велика частина незмінного, традиційного не стала предметом аналітичної свідомості, як культуру, втілену в трьох поколіннях, які перебувають у безперервному контакті» (Мид, 1988). Без письмових 
та інших засобів фріксації соціокультурного досвіду люди змушені були включати кожне вміння в свою свідомість, зберігати його в пам'яті і у відпрацьованих формах дій кожного покоління дорослих (Мид, 1988). Ті, хто довше за всіх був живим свідком у цій культурі, зазначає М. Мід, слугували зразком для більш молодих; від їх дій і рішень залежало схвалення або несхвалення способу життя «недорослих». Тому, щоб зберегти спадкоємність у культурі, люди похилого віку були потрібні (Мид, 1988). Будучи зберігачами основних знань і навичок, вони не могли уявити майбутнього своїх дітей, відмінного від їх власного способу життя, і тому виховували в своїх нащадках почуття незмінної спадкоємності способу життя. Цю мудрість життя молоді сприймали беззаперечно, бо їх спосіб життя будувався за аналогією зі способом життя батьків і дідів. Люди похилого віку були зразком для наслідування і шанування, вони втілювали в собі культуру, успішно передаючи молодим поколінням символічні значення норм, висловлювань, цінностей і стереотипів поведінки. Старше покоління незмінно користується в постфігуративному суспільстві шануванням. Збереження і трансляція такого типу культури залежить від настанов старших і від того майже незнищенного сліду, який залишають вони в душах молодих. Таке суспільство живе ніби «поза часом», із великою обережністю сприймаючи щось нове, виступаючи проти будь-яких змін, із підозрою ставлячись до реформ і нововведень, обстоюючи дотримання традицій, що обумовлює превалювання в міжпоколінній комунікації складової історичного минулого.

Однак із прискоренням технічного та соціального прогресу індустріального суспільства досвід попередніх поколінь стає уже недостатнім. Центр ваги в цьому типі культури, що отримав у термінології М. Мід назву конфрігуративного, переноситься зі стійкого минулого на рухому сучасність, сьогодення. Типовою стає орієнтація не стільки на старших, скільки на сучасників, схожих за віком і досвідом. Молодь сама виробляє стиль поведінки, цінності, орієнтації, фрормує своє уявлення про світ, успіх, сенс життя. У цій ситуації досвід предків не може принести конструктивну користь, молодь повинна знайти вирішення своїх проблем самостійно. Нові обставини вносять значні зміни в життя поколінь і породжують розрив у спадкоємності традицій. I тоді молодь звертається за підтримкою один до одного, ігноруючи авторитет старших. Роль наставників виконують однолітки: вони визначають нові моделі поведінки, пропонують інші цінності, стиль життя. Це неминуче призводить до поступового зменшення впливу традицій, скорочуючи їх життєвий простір. «Минуле, колись представлене живими людьми, стає туманним, його легше відкинути або ж спотворити в спогадах» (Мид, 1988). У результаті часова складова минулого в комунікації зменшується, і починає переважати теперішній час.

У префігуративному суспільстві, де темп розвитку стає настільки швидким, що минулий досвід вже не лише недостатній, а й часто виявляється шкідливим, заважаючи сміливим і прогресивним підходам до вирішення нових, небачених раніше завдань, переважною стає орієнтація на майбутнє. У такому суспільстві не лише молодь вчиться у старших, але й старші все більше прислухаються до молоді. «Тепер уже старші за віком люди не можуть змусити молоду людину слухатися їх на тій підставі, що вони старші і краще все знають, оскільки об- 
ставини, в яких доведеться жити молодому поколінню, докорінно відрізняються від тих, в яких жили їхні батьки» (Мид, 1988). Молодь з її префрігуративним усвідомленням ще невідомого майбутнього наділяється в цьому суспільстві всіма правами, люди похилого віку, навпаки, втрачають право вирішального голосу. У префігуративному суспільстві часова складова минулого втрачає цінність. Домінує сьогодення і майбутнє.

Зміна часових координат у міжпоколінній комунікації можна також простежити, якщо скористатися класифікацією типів культур, запропонованою М. Петровим (1991). Він виокремлює три типи кодування і трансляції знань: особистоіменний, професійно-іменний та універсально-понятійний. Першим типом культури, характерним для первісних суспільств, на його думку, є особистоіменний, де основою комунікативного коду є ім'я - адреса, що виконує функцію включення індивіда в соціальність. Тут знання, точніше, часткові програми дій у типізованих ситуаціях колективних дій розподілені в дорослі, або «мисливські», імена, які становлять «золотий знаковий фонд такого співтовариства». Процес передання культурного досвіду і соціалізації здійснюється шляхом ініціації - «введення індивіда в ім'я». При цьому індивід просто «розчиняється в тексті імені, ототожнюючи себе з усіма колишніми його носіями», і приймає на себе всі ролі, норми поведінки, які містяться в тексті, прив'язаному до цього імені. «Людина в особисто-іменному типі культур “тричі народжується” для суспільства: як дитина, як доросла і як старша людина, отримуючи в кожному акті народження особливі імена» (Петров, 1991, с. 98). Таким чином, в особистоіменному типі культури, як і в постфігуративному, якщо провести паралель із класифікацією, запропонованою М. Мід, переважним $є$ вектор минулого. Вся комунікація поколінь ґрунтується на традиціях. Старійшини, або старці, тобто «колишні носії дорослих імен», здійснюють підготовку та безпосереднє програмування молодих членів суспільства в дорослі імена, яке відбувається в процесі ритуалів посвячення, тим самим забезпечуючи функціонування трансляційного механізму в особисто-іменному типі культури. Культурозберігаючу функцію виконує пам'ять старців, що є, по суті, «тією фундаментальною бібліотекою» особисто-іменного кодування, в якій зберігається «енциклопедія» первісної соціальності: імена-адреси розподілу знання та індивідів і пов'язані з іменами тексти (Петров, 1991, с. 100).

Отже, можемо констатувати, що в суспільстві, заснованому на особистоіменному кодуванні, процес міжпоколінної комунікації, що є механізмом спадкоємності поколінь, здійснюється при безпосередній найактивнішій участі і під найсуворішим контролем старійшин, які зберігають у своїй пам'яті весь запас знань, якими володіє суспільство. Вони є гарантами спадкоємності в розвитку культури, минулим, яке координує, скеровує сьогодення, яке, в свою чергу, цілком і повністю спирається на це минуле.

Перехід до нового типу культури, в якому домінує професійно-іменне кодування, стає можливим, як зазначає М. Петров (1991), із появою перших масових професій, які забезпечують технологічні умови для такого переходу. Головною відмінною рисою цього типу культури він називає «масове програмування індивідів в одне ім'я», оскільки зростання кількості типізованих ситуацій індивідуальної 
соціально значущої дії стало підставою для «типізації індивідів у масову групупрофесію, де кожен “робить одне і те саме”. В результаті з'явилася можливість використовувати текст діяльності свого колеги по професії, оскільки ці тексти ідентичні» (с. 106). Професійно-іменне кодування дало змогу вийти за межі місткості пам'яті старійшин. Автор вказує дві причини, які стали для цього підставою: перша - зростання «в технологічному арсеналі соціальності частки ситуацій індивідуального, що використовує складні знаряддя, дії, на шкоду ситуацій колективної дії», і друга - поява «сім'ї як дуже місткого й ефективного транслятора освоєного старшими знання, яке передається підростаючому поколінню методами прямого підключення до практичної діяльності старших» (Петров, 1991, с. 105). Саме з появою в суспільстві інституту сім'ї передання накопиченого старшими досвіду здійснюється, в основному, шляхом безпосереднього включення дитини в діяльність дорослих. Дитина виконує підсобні функції в батьківській родині або поза домом, стаючи, наприклад, учнем у ремісничому цеху. Діти переймають культурносоціальні навички, засвоюючи способи дії не стільки в процесі мовної комунікації, скільки безпосередньо виконуючи певну роботу. Таким чином, змінюється механізм соціальної спадковості: соціокультурні функції старійшин тепер виконує сім'я, в межах якої передаються з покоління в покоління знання і навички. Але суспільство і в разі професійно-іменного способу трансляції культури, як і раніше, є традиційним, тобто роль і значення традиції (минулого) так само високі. У міжпоколінній комунікації минуле, як і раніше, відіграє вирішальну роль, але позиції його дещо слабшають, все більше поступаючись теперішньому. Причина такого зміщення акцентів у часовій складовій міжпоколінної комунікації, очевидно, в тому, що престиж людини всередині сім'ї визначається вже не стільки віком, скільки працездатністю, хоча старі в такому суспільстві все ще посідають почесне місце, користуються повагою.

Виникнення універсально-понятійного типу соціального кодування М. Петров (1991) пов'язує з «диференціацією фрізичної та розумової праці, тобто розщепленням єдиного раніше суб'єкта діяльності на програмуючу і виконавчу складові» (с. 145). Із прискоренням темпів економічного розвитку термін служби впроваджуваних у виробництво технологій швидко скорочується, що унеможливлює трансляцію навичок через сімейний контакт поколінь, оскільки таке поняття, як «професія на все життя», при сучасних змінах у технологічній сфері стає спірним. Трансляція форм діяльності і знання від покоління до покоління відбувається в абстрактній універсально-логічній формі, коли весь корпус знань записується за допомогою логіки в текстах. Для того, щоб оволодіти професійними чи іншими знаннями, вже не обов'язкова наявність інституту старійшин, сім'ї - їх замінює навчальна, довідкова література. Особистість, а не традиція, стала головною цінністю в сучасному суспільстві. Міжпоколінна комунікація в такій ситуації вже не орієнтована на зв'язок із минулим. Суспільство не оглядається в минуле - воно дивиться в майбутнє. Відбувається розрив із традицією.

\section{- Висновки}

Таким чином, доведено, що процеси міжпоколінної комунікації, як правило, мають спонтанний характер, зумовлений типом суспільства, структури влади 
та ін. На підставі аналізу різних типів суспільства, запропонованих М. Мід та М. Петровим, визначено, що в просторі міжпоколінної комунікації з'являються певні деструктивні елементи, пов'язані з виключною орієнтацією на теперішнє, порушенням зв'язку між минулим, теперішнім і майбутнім, відбувається розрив у діалозі поколінь. З'ясовано, що міжпоколінна комунікація ускладнюється й іншими чинниками, зокрема, специфрікою сучасної соціалізації поколінь, що вимагає звернути особливу увагу на конфлікти в міжпоколінній комунікації. Подальше дослідження суті міжпоколінної комунікації та конфрліктів у її просторі сприятиме виробленню способів налагодження механізму соціокультурної спадкоємності.

\section{Список використаних джерел}

Дунаев, Р.А. (2016). М. К. Петров: проблема социокода и диалог поколений. В Наследие М. К. Петрова: философия, культурология, науковедение, регионалистика (c. 202-204). Белгород: Белгородский государственный институт искусств и культуры.

Мид, М. (1988). Культура и мир детства (Ю. А. Асеев, Пер.). Москва: Наука.

Ортега-и-Гассет, Х. (2016). Восстание масс (А. Гелескул, Пер.). Москва: АСТ.

Парахонский, Б.А. (1989). Коммуникация и культурная среда. Вопросы философиии, 7 , 24-27.

Петров, М.К. (1991). Язык, знак, культура. Москва: Наука.

Feuer, L.S. (1969). The Conflict of Generation. The Character and Significance of Student Movements (3rd ed.). New York: Basic Books.

McLuhan, M. (1994). Understanding Media: The Extensions of Man. New York: The MIT Press.

\section{- References}

Dunaev, R.A. (2016). M. K. Petrov: problema sotciokoda i dialog pokolenii [M.K. Petrov: the problem of socio-code and the dialogue of generations]. In Nasledie M. K Petrova: filosofiia, kulturologiia, naukovedenie, regionalistika [Heritage of M.K. Petrov: Philosophy, Cultural Studies, Science of Science, Regional Studies] (pp. 202-204). Belgorod: Belgorodskii gosudarstvennyi institut iskusstv i kultury [in Russian].

Feuer, L.S. (1969). The Conflict of Generation. The Character and Significance of Student Movements (3rd ed.). New York: Basic Books [in English].

McLuhan, M. (1994). Understanding Media: The Extensions of Man. New York: The MIT Press [in English].

Mead, M. (1988). Kultura i mir detstva [Culture and the world of childhood] (lu. A. Aseev, Trans.). Moscow: Nauka [in Russian].

Ortega y Gasset, J. (2016). Vosstanie mass [Revolt of the masses] (A. Geleskul, Trans.). Moscow: AST [in Russian].

Parakhonskii, B.A. (1989). Kommunikatciia i kulturnaia sreda [Communication and cultural environment]. Voprosyi filosofii, 7, 24-27 [in Russian].

Petrov, M.K. (1991). lazyk, znak, kultura [Language, sign, culture]. Moscow: Nauka [in Russian]. 


\title{
- TYPES OF INTERGENERATIONAL COMMUNICATION
} AS A MECHANISM OF SOCIO-CULTURAL CONTINUITY

\author{
- Mariia Makarova \\ - PhD in Cultural Studies, \\ ORCID: 0000-0001-7543-0361, e-mail: student61@ukr.net, \\ Borys Grinchenko Kyiv University, \\ Kyiv, Ukraine
}

\section{Abstract}

The purpose of the article is to characterize the essence of communication between different generations in the process of development of society, due to its specificity and differences from all other types of social communications. For neither professional nor interpersonal nor pedagogical nor mass communication is as much a source of historical development. The research methodology is to apply general scientific methods and approaches of research, in particular dialectical, which makes it possible to consider social and communicative processes in their organic integrity, to analyse the essence of communication between different generations in concrete-historical social systems. To find out how intergenerational communication is changing together with the development of society, and to identify the contradictions in the space of this communication. The relevance of the study is dictated by the fact that there is communication gap between generations, the space of mutual rejection, rejection is formed, and a "zone of silence" arises. The scientific novelty is to reveal the essence of communication in different types of societies according to the typology of M. Mead and M. Petrov. Conclusions. It is found that the processes of intergenerational communication occur in society, as a rule, spontaneously, depending on its type, power structure, socio-economic relations, etc. It has been found that the lack of intergenerational communication between the past, present and future becomes a condition for the emergence of certain destructive elements, since the focus only on the present and the specifics of modern socialization breaks the dialogue between generations. It is proved that in the conditions of crisis of social development in the intergenerational communicative space begins to form in the process of socialization of generations. Therefore, to work out ways to prevent heredity breaks in the culture there is a need for special attention to the study of conflicts in intergenerational communication.

Keywords: intergenerational communication; dialogue of generations; culture; postfigurative society; co-figurative society; pre-figurative society 


\title{
- ТИПЫ МЕЖПОКОЛЕННОЙ КОММУНИКАЦИИ
} КАК МЕХАНИЗМА СОЦИОКУЛЬТУРНОЙ ПРЕЕМСТВЕННОСТИ

\author{
- Макарова Мария Владимировна \\ Кандидат культурологии, доцент, \\ ORCID: 0000-0001-7543-0361, e-mail: student61@ukr.net, \\ Киевский университет имени Бориса Гринченко, \\ Киев, Украина
}

\section{Аннотация}

Цель статьи. Охарактеризовать сущность коммуникации между различными поколениями в процессе развития общества, обусловленной ее спецификой и отличиями от всех других видов социальных коммуникаций. Ведь ни профессиональная, ни межличностная, ни педагогическая, ни массовая коммуникации не являются в такой же степени источником исторического развития. Методология исследования заключается в применении общенаучных методов и подходов, в частности диалектического, что дает возможность рассмотреть социальные и коммуникативные процессы в их органической целостности, проанализировать сущность коммуникации между различными поколениями в конкретно-исторических социальных системах. Выяснить, как одновременно с развитием общества происходит видоизменение межпоколенной коммуникации, а также выявить противоречия в пространстве последней. Актуальность исследования продиктована тем, что между поколениями формируется пространство непонимания, взаимного отторжения, неприятия, возникает «зона молчания». Научная новизна заключается в выявлении сущности коммуникации в различных типах обществ по типологии М. Мид и М. Петрова. Выводы. Установлено, что процессы межпоколенной коммуникации происходят в обществе, как правило, спонтанно, в зависимости от его типа, структуры власти, социально-экономических отношений и пр. Выявлено, что необеспечение межпоколенной коммуникации связи между прошлым, настоящим и будущим становится условием появления определенных деструктивных элементов, так как ориентация только на настоящее и специфика современной социализации вносят разрыв в диалог поколений. Доказано, что в условиях кризиса общественного развития межпоколенное коммуникативное пространство начинает формироваться в процессе социализации поколений. Поэтому для выработки способов предотвращения разрыва преемственности в культуре возникает необходимость в особом внимании к исследованию конфликтов в межпоколенной коммуникации.

Ключевые слова: межпоколенная коммуникация; диалог поколений; культура; постфигуративное общество; кофигуративное общество; префигуративное общество 